\title{
Front Matter: Volume 8036
}

, "Front Matter: Volume 8036," Proc. SPIE 8036, Scanning Microscopies 2011: Advanced Microscopy Technologies for Defense, Homeland Security, Forensic, Life, Environmental, and Industrial Sciences, 803601 (29 June 2011); doi: $10.1117 / 12.901403$

SPIE Event: SPIE Defense, Security, and Sensing, 2011, Orlando, Florida, United SPIE. States 


\section{PROCEEDINGS OF SPIE}

\section{Scanning Microscopies 2011: Advanced Microscopy Technologies for Defense, Homeland Security, Forensic, Life, Environmental, and Industrial Sciences}

Michael T. Postek

Dale E. Newbury

S. Frank Platek

David C. Joy

Tim K. Maugel

Editors

26-28 April 2011

Orlando, Florida, United States

Sponsored and Published by

SPIE

Volume 8036 
The papers included in this volume were part of the technical conference cited on the cover and title page. Papers were selected and subject to review by the editors and conference program committee. Some conference presentations may not be available for publication. The papers published in these proceedings reflect the work and thoughts of the authors and are published herein as submitted. The publisher is not responsible for the validity of the information or for any outcomes resulting from reliance thereon.

Please use the following format to cite material from this book:

Author(s), "Title of Paper," in Scanning Microscopies 2011: Advanced Microscopy Technologies for Defense, Homeland Security, Forensic, Life, Environmental, and Industrial Sciences, edited by Michael T. Postek, Dale E. Newbury, S. Frank Platek, David C. Joy, Tim K. Maugel, Proceedings of SPIE Vol. 8036 (SPIE, Bellingham, WA, 2011) Article CID Number.

ISSN 0277-786X

ISBN 9780819486103

Published by

SPIE

P.O. Box 10, Bellingham, Washington 98227-0010 USA

Telephone +1 3606763290 (Pacific Time) · Fax +1 3606471445

SPIE.org

Copyright ( 2011, Society of Photo-Optical Instrumentation Engineers

Copying of material in this book for internal or personal use, or for the internal or personal use of specific clients, beyond the fair use provisions granted by the U.S. Copyright Law is authorized by SPIE subject to payment of copying fees. The Transactional Reporting Service base fee for this volume is $\$ 18.00$ per article (or portion thereof), which should be paid directly to the Copyright Clearance Center (CCC), 222 Rosewood Drive, Danvers, MA 01923. Payment may also be made electronically through CCC Online at copyright.com. Other copying for republication, resale, advertising or promotion, or any form of systematic or multiple reproduction of any material in this book is prohibited except with permission in writing from the publisher. The CCC fee code is 0277-786X/11/\$18.00.

Printed in the United States of America.

Publication of record for individual papers is online in the SPIE Digital Library.

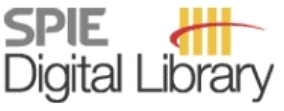

SPIEDigitalLibrary.org

Paper Numbering: Proceedings of SPIE follow an e-First publication model, with papers published first online and then in print and on CD-ROM. Papers are published as they are submitted and meet publication criteria. A unique, consistent, permanent citation identifier (CID) number is assigned to each article at the time of the first publication. Utilization of CIDs allows articles to be fully citable as soon as they are published online, and connects the same identifier to all online, print, and electronic versions of the publication. SPIE uses a six-digit CID article numbering system in which:

- The first four digits correspond to the SPIE volume number.

- The last two digits indicate publication order within the volume using a Base 36 numbering system employing both numerals and letters. These two-number sets start with 00, 01, 02, 03, 04, $05,06,07,08,09,0 A, 0 B \ldots$. OZ, followed by 10-1Z, 20-2Z, etc.

The CID number appears on each page of the manuscript. The complete citation is used on the first page, and an abbreviated version on subsequent pages. Numbers in the index correspond to the last two digits of the six-digit CID number. 


\section{Contents}

vii Conference Committee

xi Introduction

\section{KEYNOTE SESSION}

803602 Is scanning electron microscopy/energy dispersive $x$-ray spectroscopy (SEM/EDS) quantitative? Effect of specimen shape (Keynote Paper) [8036-01]

D. E. Newbury, N. W. M. Ritchie, National Institute of Standards and Technology (United States)

\section{FORENSICS}

803604 Analysis of particles produced during airbag deployment by scanning electron microscopy with energy dispersive $x$-ray spectroscopy and their deposition on surrounding surfaces: $a$ mid-research summary [8036-18]

J. M. Wyatt, U.S. Army Criminal Investigation Lab. (United States)

803605 Probative value of gunshot residue on victims of shootings and comparison of gunshot residue results with modern technology versus older testing of samples [8036-04] R. S. White, West Virginia State Police, Retired (United States); W. J. Mershon, Tescan USA Inc. (United States)

803606 Scientific working group on gunshot residue (SWGGSR): a progress report [8036-05] M. A. Trimpe, Hamilton County Coroner's Lab. (United States)

803607 Characterization and source identification of fugitive dusts by light and electron microscopy [8036-06]

R. S. Brown, MVA Scientific Consultants (United States)

803608 Application possibilities of several modern methods of microscopy and microanalysis in forensic science field [8036-07]

M. Kotrlý, I. Turková, Institute of Criminalistics Prague (Czech Republic)

\section{ADVANCEMENTS IN SCANNING ELECTRON MICROSCOPY}

8036 OD Advanced image composition with intra-frame drift correction [8036-12]

P. Cizmar, A. E. Vladár, M. T. Postek, National Institute of Standards and Technology (United States)

8036 OE The characterization of nanoparticles using analytical electron microscopy [8036-13] W. B. Hill, MVA Scientific Consultants (United States) 
8036 OF Transmission electron microscopy of electrospun GaN nanofibers [8036-14]

J. L. Robles-García, A. Meléndez, Univ. of Puerto Rico at Humacao (United States); D. Yates, J. J. Santiago-Avilés, Univ. of Pennsylvania (United States); I. Ramos, Univ. of Puerto Rico at

Humacao (United States); E. M. Campo, Univ. of Pennsylvania (United States)

8036 OG Study of LCE nanocomposites through electron microscopy [8036-15]

N. Torras, J. Jobet, Instituto de Microelectrónica de Barcelona (Spain); J. E. Marshall, Univ. of Cambridge (United Kingdom); K. Zinoviev, Ctr. Instituto de Microelectrónica de Barcelona (Spain); D. Yates, L. Rotkina, Univ. of Pennsylvania (United States); J. Esteve, Instituto de Microelectrónica de Barcelona (Spain); E. M. Terentjev, Univ. of Cambridge (United Kingdom); E. M. Campo, Univ. of Pennsylvania (United States)

$8036 \mathrm{OH} \quad$ Morphological classification and microanalysis of tire tread particles worn by abrasion or corrosion [8036-16]

G. F. Crosta, Univ. degli Studi di Milano-Bicocca (Italy)

8036 Ol Nanodispersion, nonlinear image filtering, and materials classification [8036-17]

G. F. Crosta, Univ. degli Studi di Milano-Bicocca (Italy); J. S. Lee, Univ. of Massachusetts, Lowell (United States)

\section{ADVANCEMENTS IN HELIUM ION MICROSCOPY}

8036 OK Investigation of cellular interactions of nanoparticles by helium ion microscopy [8036-20] B. W. Arey, V. Shutthanandan, Y. Xie, A. Tolic, N. Williams, G. Orr, Pacific Northwest National Lab. (United States)

$80360 \mathrm{M}$ Creating nanohole arrays with the helium ion microscope [8036-22] M. Ananth, L. Stern, D. Ferranti, C. Huynh, J. Notte, L. Scipioni, C. Sanford, B. Thompson, Carl Zeiss NTS, LLC (United States)

803600 Secondary electron emission spectra and energy selective imaging in helium ion microscope [8036-24]

Yu. Petrov, O. Vyvenko, St. Petersburg State Univ. (Russian Federation)

\section{ADVANCES IN SCANNED PROBE MICROSCOPIES I}

8036 OP A metrological scanning probe microscope based on a quartz tuning fork detector [8036-25]

B. Babic, C. H. Freund, M. Lawn, J. R. Miles, J. Herrmann, National Measurement Institute (Australia)

$80360 Q \quad$ Measurement strategies and uncertainty estimations for pitch and step height calibrations by metrological AFM [8036-26]

V. Korpelainen, J. Seppä, A. Lassila, Ctr. for metrology and accreditation (Finland)

8036 OR Study of a large range metrological atomic force microscope applied for calibration of a vertical PZT stage [8036-27]

S. H. Wang, S. L. Tan, G. XU, A*STAR National Metrology Ctr. (Singapore) 
8036 OS Traceable calibration of a critical dimension atomic force microscope [8036-28]

R. Dixson, N. G. Orji, C. D. McGray, J. Geist, National Institute of Standards and Technology (United States)

\section{ADVANCES IN SCANNED PROBE MICROSCOPIES II}

8036 OT Particle number density gradient samples for nanoparticle metrology with atomic force microscopy [8036-29]

M. A. Lawn, National Measurement Institute (Australia); R. V. Goreham, Univ. of South Australia (Australia); J. Herrmann, Å. K. Jämting, National Measurement Institute (Australia)

8036 OU Development of photomask linewidth measurement and calibration using AFM and SEM in NMIJ [8036-30]

K. Sugawara, O. Sato, I. Misumi, S. Gonda, M. Lu, National Metrology Institute of Japan (Japan)

8036 OV New developments at PTB in 3D-AFM with tapping and torsion AFM mode and vector approach probing strategy [8036-31]

G. Dai, W. Häßler-Grohne, D. Hüser, H. Wolff, J. Fluegge, H. Bosse, Physikalisch-Technische

Bundesanstalt (Germany)

\section{ADVANCES IN OPTICAL MICROSCOPY}

803610 Through-focus scanning optical microscopy [8036-36]

R. Attota, R. G. Dixson, A. E. Vladár, National Institute of Standards and Technology (United States)

803612 Dispersion free all reflective confocal microscope objective [8036-38]

W. J. Walecki, Sunrise Optical LLC (United States); M. Scaggs, Neoteric Concepts, LLC (United States); P. S. Walecki, F. Szondy, Sunrise Optical LLC (United States)

803613 Use of fluorescence and scanning electron microscopy as tools in teaching biology [8036-40]

N. Ghosh, West Texas A\&M Univ. (United States); J. Silva, A. Vazquez, Eastfield College (United States); A. B. Das, Orissa Univ. of Agriculture \& Technology (India); D. W. Smith, Univ. of North Texas (United States)

\section{PARTICLE BEAM INTERACTION WORKSHOP}

803615 3D-measurement using a scanning electron microscope with four Everhart-Thornley detectors [8036-42]

T. Vynnyk, R. Schever, E. Reithmeier, Leibniz Univ. Hannover (Germany)

Author Index 
Downloaded From: https://www.spiedigitallibrary.org/conference-proceedings-of-spie on 26 Apr 2023

Terms of Use: https://www.spiedigitallibrary.org/terms-of-use 


\title{
Conference Committee
}

\author{
Symposium Chair
}

William Jeffrey, HRL Laboratories, LLC (United States)

Symposium Cochair

Kevin P. Meiners, Office of the Secretary of Defense (United States)

Conference Chairs

Michael T. Postek, National Institute of Standards and Technology (United States)

Dale E. Newbury, National Institute of Standards and Technology (United States)

S. Frank Platek, U.S. Food and Drug Administration (United States)

Conference Cochairs

David C. Joy, The University of Tennessee (United States)

Tim K. Maugel, University of Maryland, College Park (United States)

Program Committee

Eva M. Campo, Centro Nacional de Microelectrónica (Spain)

Ronald G. Dixson, National Institute of Standards and Technology (United States)

Lucille A. Giannuzzi, L.A. Giannuzzi \& Associates LLC (United States)

Brendan J. Griffin, The University of Western Australia (Australia)

Michael A. Trimpe, Hamilton County Coroner's Laboratory (United States)

Vladimir A. Ukraintsev, Nanometrology International, Inc. (United States)

John S. Villarrubia, National Institute of Standards and Technology (United States)

András E. Vladár, National Institute of Standards and Technology (United States)

Oliver C. Wells, IBM Corporation(United States) 
Session Chairs

1 Keynote Session

Michael T. Postek, National Institute of Standards and Technology (United States)

Dale E. Newbury, National Institute of Standards and Technology (United States)

S. Frank Platek, U.S. Food and Drug Administration (United States)

2 Forensics

S. Frank Platek, U.S. Food and Drug Administration (United States)

3 Advancements in Scanning Electron Microscopy I

Eva M. Campo, University of Pennsylvania (United States)

Lucille A. Giannuzzi, L.A. Giannuzzi \& Associates LLC (United States)

4 Advancements in Scanning Electron Microscopy II

Lucille A. Giannuzzi, L.A. Giannuzzi \& Associates LLC (United States)

Eva M. Campo, University of Pennsylvania (United States)

5 Advancements in Helium Ion Microscopy

András E. Vladár, National Institute of Standards and Technology (United States)

Michael T. Postek, National Institute of Standards and Technology (United States)

6 Advances in Scanned Probe Microscopies I

Ronald G. Dixson, National Institute of Standards and Technology (United States)

Ndubuisi G. Orji, National Institute of Standards and Technology (United States)

$7 \quad$ Advances in Scanned Probe Microscopies II

Ronald G. Dixson, National Institute of Standards and Technology (United States)

Ndubuisi G. Orji, National Institute of Standards and Technology (United States)

8 Advances in Optical Microscopy

Ravikiran Attota, National Institute of Standards and Technology (United States)

Tim K. Maugel, University of Maryland, College Park (United States) 
9 Particle Beam Interaction Workshop

John S. Villarrubia, National Institute of Standards and Technology (United States)

András E. Vladár, National Institute of Standards and Technology (United States) 
Downloaded From: https://www.spiedigitallibrary.org/conference-proceedings-of-spie on 26 Apr 2023

Terms of Use: https://www.spiedigitallibrary.org/terms-of-use 


\section{Introduction}

The Scanning Microscopies 2011: Advanced Microscopy Technologies for Defense, Homeland Security, Forensic, Life, Environmental, and Industrial Sciences (SCANNING) meeting brought microscopists from all aspects of scanning microscopies (from scanned optics and probes to scanned particle beams) together in a single forum to discuss current research and new advancements in the field. This year, the SCANNING 2011 meeting joined the SPIE Defense, Security, and Sensing 2011 (DSS 2011) conference in Orlando, Florida. On the surface this does not seem intuitive but the past SCANNING meetings have had a large forensics following which is strongly supportive of both defense and homeland security. Scanned microscopies are also key investigative and research tools in all three of the topics encompassed by the meeting, as evidenced by attending other presentations of DSS 2011. It became clear that scanning microscopies are used across the gamut of topics covered by this overall symposium and merging SCANNING with this symposium was an appropriate move for the future.

Spring conferences on scanning microscopy have a history going back to 1967 with the "IITRI Scanning Electron Microscopy" series started by Dr. Om Johari. Following Dr. Johari's retirement, the SCANNING series of conferences organized by Ms. Tony Bourgholtzer of the Foundation for Advances in Medicine and Science (FAMS), continued this tradition. Early in 2007, FAMS decided to discontinue sponsorship of future SCANNING meetings. Since the FAMS announcement, a substantial amount of work went on in the background to find a solution to keep the meeting alive. SCANNING 2009 was ultimately organized through SPIE (the International Society for Optical Engineering) and as a bridge to that meeting, a highly successful spring scanning microscopy meeting was held at the National Institute of Standards and Technology (NIST) in Gaithersburg, Maryland in 2008. Subsequently, SCANNING 2009 and SCANNING 2010 were held in Monterey, California but it became clear that it was advantageous for SCANNING 2011 to ally itself with a larger meeting. Thus, it became a part of the SPIE Defense, Security, and Sensing 2011 conference in Orlando, Florida. In 2012 the SPIE Defense, Security, and Sensing conference will move to Baltimore, Maryland where the scanning microscopies research and user base is quite large. We are highly optimistic about this change in venue.

The SCANNING 2011 conference was quite successful. Sessions encompassed papers covering forensics applications, scanning electron microscopy, helium ion microscopy; scanned probe microscopy, scanned optical microscopy and particle beam microscopy. In addition, the Particle Beam Interaction Workshop 
was held for the 17th year. This workshop has been responsible for the rapid development of accurate models for particle beam, microanalysis, and scanned probe microscopy. The Scanning Microscopy in Forensic Science Short Course was also offered for the 16th year and has proven to be valuable in the training of forensic scientists across the world.

Michael T. Postek

Dale E. Newbury

S. Frank Platek David C. Joy Tim K. Maugel 